\title{
Trends in Molecular Biology of Several Fruit Trees
}

\author{
Anca Butiuc-Keul*, Dumitrana Fiț and Anca Farkas \\ Department of Molecular Biology and Biotechnology, Babeș-Bolyai University, Romania
}

Submission: December 18, 2018; Published: April 23, 2019

*Corresponding author: Anca Butiuc Keul, Department of Molecular Biology and Biotechnology, Faculty of Biology and Geology, Babeş-Bolyai University, 400084 Cluj-Napoca, Romania

\begin{abstract}
The most relevant trends in the molecular biology of several fruit trees as apple, peach, nectarine and apricots are sumarized in this article. Thus, one of the most important problem is the management of germplasm collections, that is usually due by molecular markers, that could provide valuable information about molecular characterization of cultivars, the expansion of cultivars from centres of origin, identification of synonymies, selection of new cultivars, assessment of genetic diversity/stability after conservation. Other direction of research is identification of molecular markers associated with different traits (Quantitative Trait Loci-QTL) and identification of mechanisms involved in resistance to pathogens (bacteria, viruses, fungi) and different climate conditions (drought, cold) in order to select new valuable cultivars (Molecular markerAssisted Selection-MAS).
\end{abstract}

Keywords: Fruit trees; Molecular markers; Genetic diversity; Conservation; Selection

\section{Mini Review}

Germplasm of perennial fruit species is conserved by in situ collections of in vitro culture in order to preserve the genetic resources and maintenance of biodiversity [1]. Biodiversity is fundamental for biotechnology and selection of new valuable cultivars and sustainable agriculture. Conservation methods should ensure the stability of plant species or cultivars, thus the periodic evaluation of the genetic composition of the preserved material is needed [2].

Apple (Malus $x$ domestica Borkh.) considered the economically most important fruit crop in the temperate zone [3], has a gametophytic self-incompatibility mechanism, which enforces outbreeding and a high level of heterozygosity [4]. Thus, genetic analysis by molecular markers ensure the discrimination of vegetatively propagated apple trees. Several molecular markers were used over years, but microsatellite (SSR) DNA become a popular tool for fingerprinting germplasm collections [5]. SSR markers have been successfully applied for apple tree cultivar identification [6], evaluation of genetic diversity within germplasm collections $[7,8]$ or for parent identification $[4,9]$. Apple germplasm in USA and Europe was investigated in order to identify a minimal set of markers useful for rapid discrimination of cultivars [10-13]. Molecular markers are also valuable tools for characterization of in vitro plants of fruit trees. Thus, RAPD and ISSR markers were used to prove the genetic fidelity of clonally propagated apple from adventitious buds [14,15].
Another application of molecular markers is connected with the evaluation of apple resistance to fungal pathogen Venturia inaequalis, which produces apple scab. 11 apple scab resistance genes are known up to now and several molecular markers linked to these genes are available [16], making the markerassisted selection an useful tool for breeding programs [17].

Other important fruit crops of temperate climates are apricots, peaches and nectarines. Two centres of domestication of apricot (Prunus armeniaca L.) cultivars are known as China and Central Asia-from Tien-shan to Kashmir and the secondary centers of origin is considered the near-Eastern (Iran, the Caucasus and Turkey) and Korezm regions [18]. The European cultivars grown in North America, Australia and South Africa shows the least diversity $[19,20]$. The discrimination between cultivars is difficult, but nevertheless, the Eastern European cultivars can be clearly distinguished from other cultivars of European origin $[21,22]$. Traditional methods based phenotypic descriptions do not provide enough information to trace the expansion of apricot from the centers of origin, or to identify and characterize genotypes during the breeding process. Thus, the molecular markers are also the most suitable tools for such investigation.

In case of peach and nectarine (Prunus persica (L.) Batsch), despite of a low number of origin cultivars and narrow genetic 
base [23], more than thousand new varieties were released around the world [24]. However, the diversity of this crop has been drastically reduced using improved varieties with a common genetic base [25], that has drastically reduced the genetic variability of this crop [23,26-29]. Moreover, peach is a self-compatible species and a high level of inbreeding is found, several cultivars with great breeding value show a low degree of heterozygosity [30]. Thus, a reliable and efficient method of cultivar identification is required. In Spain, the genetic diversity within peaches is also decreasing rapidly, because of the replacement of traditional varieties by introduced ones, mostly from North America [31].

There are many SSR markers for different Prunus species [32] as peach and nectarine [30,33,34], apricot [35-38]. SSR markers were also used for identification of hybrids in apricot [39]. It is well known that the selection of markers usually depends on the nature of the germplasm under study and in many cases the existence of a set of markers applied for the identification of germplasm collections was useful but not totally transferable to the others. Another challenge is to find a minimal pannel of molecular markers useful for discrimination of cultivars. Aranzana et al. [25,33] characterized and differentiated over 200 cultivars of peaches and nectarines commonly grown in Spain, using a selected set of 16 microsatellite markers, Bouhadida et al. [40] characterized 94 peaches cultivars also grown in Spain with 15 SSR microsatellite markers and Rojas et al. [41] differentiated 117 cultivars of peaches and nectarine with only 7 SSR markers. Other specific set of SSR markers were valuable for investigation of Asian [42,43] and Tunisian peach germplasm [44,45].

Genetic control of complex traits has been accomplished through quantitative trait loci (QTLs) analysis of biparental populations resulting from crosses between peach and related species [46]. A pedigree-based analysis to map QTLs for a diverse peach breeding pedigree, identified several well-supported QTLs for at least five of the eight traits investigated by FresnedoRamírez et al. [47].

Molecular characterization of fruit trees has multiple application in biotechnology and agriculture as germplasm identification and preservation, genotyping, selection of new valuable cultivars, improvement of quantitative traits.

\section{References}

1. Panis B, Lambardi M (2005) Status of cryopreservation technologies in plants (crops and forest trees). In: The Role of Biotechnology for the Characterization and Conservation of Crop, Forest, Animal and Fishery Genetic Resources in Developing Countries. FAO, Turin, Italy, pp 43-54.

2. Martín C, Senula A, González I, Acosta A, Keller ER, et al. (2013) Genetic identity of three mint accessions stored by different conservation procedures: field collection, in vitro and cryopreservation. Genet Resour Crop Evol 60(1): 242-249.

3. Sansavini S, Donati F, Costa F, Tartarini S (2004) Advances in apple breeding for enhanced fruit quality and resistance to biotic stresses: New varieties for the European market. J Fruit Orn Plant Res 12: 13-51.
4. Kitahara K, Matsumoto S, Yamamoto T, Soejima J, Kimura T, et al. (2005) Parent identification of eight apple cultivars by S-RNase analysis and simple sequence repeat markers. Hortsci 40(2): 314-317.

5. Cipriani G, Marrazzo MT, Di Gaspero G, Pfeiffer A, Morgante M, Testolin $\mathrm{R}$ (2008) A set of microsatellite markers with long core repeat optimized for grape (Vitis spp.) genotyping. BMC Plant Biol 8: 127.

6. Galli Z, Halász G, Kiss E, Heszky L, Dobránszki J (2005) Molecular identification of commercial apple cultivars with microsatelite markers. Hort Sci 40(7): 1974-1977.

7. Guarino C, Santoro S, De Simone L, Lain O, Cipriani G, et al. (2006) Genetic diversity in a collection of ancient cultivars of apple (Malus $x$ domestica Borkh.) as revealed by SSR-based fingerprinting. J Hortic Sci Biotechnol 81: 39-44.

8. Pereira-Lorenzo S, Ramos-Cabrer AM, Diáz-Hernández MB (2007) Evaluation of genetic identity and variation of local apple cultivars (Malus $x$ domestica Borkh.) from Spain using microsatellite markers. Genetic Res Crop Evol 54(2): 405-420.

9. Patocchi A, Fernandez-Fernandez F, Evans K, Silfverberg-Dilworth E, Matasci C, et al. (2009) Development of a set of apples SSRs markers spanning the apple genome, genotyping of HiDRAS plant material and validation of genotyping data. Acta Hort 814: 603-608.

10. Silfverberg-Dilworth E, Matasci CL, Van de Weg WE, Van Kaauwen MPW, Walser M, et al. (2006) Microsatellite markers spanning the apple (Malus $\times$ domestica Borkh.) genome. Tree Genetics \& Genomics 2(4): 202-224.

11. Zhang C, Chen X, He T, Liu X, Feng T, et al. (2007) Genetic structure of Malus sieversii population from Xinjiang, China, revealed by SSR markers. J Genet Genomics 34(10): 947-955.

12. Gharghani A, Zamani Z, Talaie A, Oraguzie NC, Fatahi R, et al. (2009) Genetic identity and relationships of Iranian apples (Malus $\times$ domestica Borkh) cultivars and landraces, wild apple species and representative old apple cultivars based on SSR markers. Genet Resour Crop Evol 56(6): 829-842.

13. Farrokhi J, Darvishzadeh R, Naseri L, Mohseni AM, Hatami MH (2011) Evaluation of genetic diversity among Iranian apple (Malus $\times$ domestica Borkh.) cultivars and landraces using simple sequence repeat markers. Austr J Crop Sci 5(7): 815-821.

14. Modgil M, Mahajan K, Chakrabarti SK, Sharma DR, Sobti RC (2005) Molecular analysis of genetic stability in micropropagated apple rootstock MM106. Sci Hort 104(2): 151-160.

15. Yi JY, GiAn Lee, Chung JW, Lee YY, Kwak JG, etal. (2015) Morphological and genetic stability of dormant apple winter buds after cryopreservation. Korean J Plant Res 28(6): 697-703.

16. Gessler C, Patocchi A, Sansavini S, Tartarini S, Gianfranceschi L (2006) Venturia inaequalis resistance in apple. Crit Rev Plant Sci 25: 473-503.

17. Soriano JM, Joshi SG, van Kaauwen M, Noordijk Y, Groenwold R, et al. (2009) Identification and mapping of the novel apple scab resistance gene Vd3. Tree Genetics \& Genomes 5(3): 475-482.

18. Vavilov NI (1951) Phytogeographical basis of plant breeding. In: Chester, KS (transl.), The origin, variation, immunity and breeding of cultivated plants. Chron Bot 13: 13-54.

19. Mehlenbacher SA, Cociu V, Hough LF (1991) Apricots (Prunus). In: Moore JN, Ballington JR (Eds.), Genetic resources of temperate fruit and nut crops. International Society for Horticultural Science, Wageningen, Netherlands, pp. 65-107.

20. Martín C, Herrero M, Hormaza JI (2011) Molecular characterization of apricot germplasm from an old stone collection. PLoS ONE 6(8): e23979. 
21. Faust M, Surányi D, Nyujtó F (1998) Origin and dissemination of apricot. Hortic Rev 22: 225-266.

22. Verde I, Abbott AG, Scalabrin S, Jung S, Shu S, et al. (2013) The highquality draft genome of peach (Prunus persica) identifies unique patterns of genetic diversity, domestication and genome evolution. Nat Genet 45(5): 487-494.

23. Scorza R, Sherman WB, Lightner GW (1988) Inbreeding and coancestry of low chill short fruit development period freestone peaches and nectarines produced by the University of Florida breeding program. Fruit Var J 42(3): 79-85.

24. Llácer G, Alonso M, Rubio-Cabetas MJ, Batlle I, Iglesias I, et al. (2009) Situación del material vegetal del melocotonero utilizado en España. ITEA 105: 67-83.

25. Aranzana MJ, Carbó J, Arús P (2003) Microsatellite variability in peach [Prunus persica (L.) Batsch]: cultivar identification, marker mutation, pedigree inferences and population structure. Theor Appl Genet 106(8): 1341-1352.

26. Aranzana MJ, Abbassi E-K, Howad W, Arus P (2010) Genetic variation, population structure and linkage disequilibrium in peach commercial varieties. BMC Genet 11: 69.

27. Cao K, Wang L, Zhu G, Fang W, Chen C, et al. (2012) Genetic diversity, linkage disequilibrium, and association mapping analyses of peach (Prunus persica) landraces in China. Tree Genetics \& Genomes 8(5): 975-990.

28. Cao K, Zheng Z, Wang L, Liu X, Zhu G, et al. (2014) Comparative population genomics reveals the domestication history of the peach, Prunus persica and human influences on perennial fruit crops. Genome Biol 15(7): 415.

29. Abidi W, Moreno MA, Gogorcena Y (2017) Genetic diversity among nectarine [Prunus persica (L.) Batsch] seedlings in agronomical and biochemical fruit quality traitsjournal of new sciences. Agric \& Biotechnol 48(1): 2888-2896.

30. Testolin R, Marrazo T, Cipriani G, Quarta R, Verde I, et al. (2000) Microsatellite DNA in peach [Prunus persica (L.) Batsch] and its use in fingerprinting and testing the genetic origin of cultivars. Genome 43(3): 512-520.

31. Llácer G, Alonso JM, Rubio-Cabetas MJ, Battle I, Iglesias I, et al. (2009) Peach industry in Spain. J Am Pomol Soc 63(3): 128-133.

32. Dettori MT, Micali S, Giovinazzi J, Scalabrin S, Verde I, et al. (2015) Mining microsatellites in the peach genome: development of new long-core SSR markers for genetic analyses in five Prunus species. Springer Plus 4: 337.

33. Aranzana MJ, Pineda A, Cosson P, Dirlewanger E, Ascasibar J, et al. (2003) A set of simple-sequence repeat (SSR) markers covering the Prunus genome. Theor Appl Genet 106(5): 819-825.
34. Ahmad R, Potter D, Southwick SM (2004) Genotyping of peach and nectarine cultivars with SSR and SRAP molecular markers. J Amer Soc Hort Sci 129(2): 204-210.

35. Messina R, Lain O, Marrazzo MT, Cipriani G, Testolin R (2004) New set of microsatellite loci isolated in apricot. Molec Ecol Notes 4(3): 432434.

36. Maghuly F, Fernandez EB, Ruthner S, Pedryc A, Laimer M (2005) Microsatellite variability in apricots (Prunus armeniaca L.) reflects their geographic origin and breeding history. Tree Genet Genom 1: 151-165.

37. Vilanova S, Soriano JM, Lalli DA, Romero C, Abbott AG, et al. (2006) Development of SSR markers located in the G1 linkage group of apricot (Prunus armeniaca L.) using a bacterial artificial chromosome library. Molec Ecol Notes 6(3): 789-791.

38. Pedryc A, Ruthner S, Hermán R, Krska B, Hegedus A, et al. (2009) Genetic diversity of apricot revealed by a set of SSR markers from linkage group G1. Sci Hortic 121(1): 19-26.

39. Comlekcioglu S, Kuden AB (2015) Evaluation of pech and nectarine hybrids using SSR marker assisted selection approach. Acta Hortic 1084: 105-111.

40. Bouhadida M, Moreno MA, Gonzalo MJ, Alonso JM, Gogorcena Y (2011) Genetic variability of introduced and local spanish peach cultivars determined by SSR markers. Tree Genet Genom 7(2): 257-270.

41. Rojas G, Méndez MA, Muñoz C, Lemus G, Hinrichsen P (2008) Identification of a minimal microsatellite marker panel for the fingerprinting of peach and nectarine cultivars. Electronic J Biotechnol 11(5).

42. Xie R, Li X, Chai M, Song L, Jia H, et al. (2010) Evaluation of the genetic diversity of Asian peach accessions using a selected set of SSR markers. Sci Hortic 125(4): 622-629.

43. Shen ZJ, Ma RJ, Cai ZX, Yu ML, Zhang Z (2015) Diversity, population structure, and evolution of local peach cultivars in China identified by simple sequence repeats. Genet Mol Res 14(1): 101-117.

44. Bourguiba H, Krichen L, Audergon JM, Khadari B, Trifi-Farah N (2010) Impact of mapped SSR markers on the genetic diversity of apricot (Prunus armeniaca L.) in Tunisia. Plant Mol Biol Report 28(4): 578-587.

45. Krichen L, Audergon JM, Trifi-Farah N (2014) Assessing the genetic diversity and population structure of Tunisian apricot germplasm. Sci Hort 172: 86-100.

46. Olukolu BA, Kole C (2012) Molecular mapping of complex traits. In Kole C, Abbott AG (Eds.) Genetics, genomics and breeding of crop plants. CRC Press, Boca Raton, USA, p. 126-157.

47. Fresnedo-Ramírez J, Bink MCAM, van de Weg E, Famula TR, Crisosto $\mathrm{CH}$, et al. (2015) QTL mapping of pomological traits in peach and related species breeding germplasm. Mol Breeding 35: 166.

This work is licensed under Creative

Commons Attribution 4.0 License

DOI: 10.19080/JOJHA.2018.01.555589

\section{Your next submission with Juniper Publishers will reach you the below assets}

- Quality Editorial service

- Swift Peer Review

- Reprints availability

- E-prints Service

- Manuscript Podcast for convenient understanding

- Global attainment for your research

- Manuscript accessibility in different formats

( Pdf, E-pub, Full Text, Audio)

- Unceasing customer service

Track the below URL for one-step submission https://juniperpublishers.com/online-submission.php 